\title{
Chemical reduction of an unbuffered nitrate solution using catalyzed and uncatalyzed nanoscale iron particles
}

\author{
Ya Hsuan Liou ${ }^{\text {a }}$, Shang-Lien Lo ${ }^{\text {a }}$, Chin-Jung Lin ${ }^{\mathrm{a}, *}$, Wen Hui Kuan ${ }^{\mathrm{b}}$, Shih Chi Weng ${ }^{\mathrm{a}}$ \\ ${ }^{a}$ Research Center for Environmental Pollution Prevention and Control Technology, Graduate Institute of Environmental Engineering, \\ National Taiwan University, Taipei 106, Taiwan \\ ${ }^{\mathrm{b}}$ Department of Environmental and Safety Engineering, Ming-Chi Institute of Technology, Taishan, Taipei Hsien 243, Taiwan
}

Received 26 March 2005; received in revised form 20 June 2005; accepted 24 June 2005

Available online 2 August 2005

\begin{abstract}
Uncatalyzed and catalyzed nanoscale $\mathrm{Fe}^{0}$ systems were employed for the denitrification of unbuffered $40 \mathrm{mg} \mathrm{NL}^{-1}$ nitrate solutions at initial neutral $\mathrm{pH}$. Compared to microscale $\mathrm{Fe}^{0}(<100 \mathrm{mesh})$, the efficiency and rate of nitrate removal using uncatalyzed and catalyzed nano- $\mathrm{Fe}^{0}$ were highly promoted, in which the maximum promoted rate was obtained using copper-catalyzed nano- $\mathrm{Fe}{ }^{0}$ (nano-Cu/Fe). Nitrate first-order degradation rate constants $\left(k_{\text {obs }}\right)$ decreased significantly $(>70 \%)$ with aged nano- $\mathrm{Fe}^{0}$ and aged nano-Cu/Fe, and were recovered with $\mathrm{NaBH}_{4}$ as reductants at levels of about 85 and $75 \%$, respectively. Activation energies $\left(E_{\mathrm{a}}\right)$ of nitrate reduction over the temperature range of $10-60{ }^{\circ} \mathrm{C}$ were $42.5 \mathrm{~kJ} \mathrm{~mol}^{-1}$ for microscale $\mathrm{Fe}^{0}, 25.8 \mathrm{~kJ} \mathrm{~mol}^{-1}$ for nano- $\mathrm{Fe}^{0}$ and $16.8 \mathrm{~kJ} \mathrm{~mol}^{-1}$ for nano- $\mathrm{Cu} / \mathrm{Fe}$. Unlike microscale $\mathrm{Fe}^{0}$, the kinetics of denitrification by nano- $\mathrm{Fe}^{0}$ and nano- $\mathrm{Cu} / \mathrm{Fe}$ began to show characteristics of mass transport in addition to chemical reaction control. Ammonium was the predominant end product in all the systems. However, as for nitrite, $40 \%$ of the degraded nitrate persisted in the nano- $\mathrm{Cu} / \mathrm{Fe}$ system. Thus, relative to nano- $\mathrm{Cu} / \mathrm{Fe}$, nano- $\mathrm{Fe}^{0}$ is a potential reductant for denitrification of groundwater as far as toxic nitrite generation is concern.
\end{abstract}

(C) 2005 Elsevier B.V. All rights reserved.

Keywords: Nanoscale; Iron; Bimetals; Denitrification; Nitrate

\section{Introduction}

Extensive studies over the past 15 years have demonstrated that chemical reduction of many substances in the environment, such as halogenated organic compounds [1-6], heavy metals [7-11] and oxo-anions [6,10-22] can be coupled to $\mathrm{Fe}^{0}$ oxidation. In the reductive dechlorination reaction by $\mathrm{Fe}^{0}$, for example, the anodic $\mathrm{Fe}^{0}$ is oxidized into $\mathrm{Fe}^{2+}$ ions, and chlorinated hydrocarbons as electron acceptors are converted to hydrocarbons and chlorides. The detoxifcation efficacy, low cost, and benign environmental impact of $\mathrm{Fe}^{0}$ facilitate the development of a process to remediate environmental contaminants. Particularly groundwater remediation is concerned.

\footnotetext{
* Corresponding author. Tel.: +886 223625373 ; fax: +886 23928821 .

E-mail address: d89541005@ntu.edu.tw (C.-J. Lin).
}

Nitrate widely occurs in ground and surface waters as a result from the over-fertilization, concentrated animal feeding operations and industrial waste effluent discharge [23]. The potential effect to human health is actually related to nitrite, which forms upon reduction of nitrate in human gut, and can lead to blue baby syndrome and cancer [24]. $\mathrm{Fe}^{0}$ has been believed to act as an electron donor to reduce nitrate [10-22]. Both direct reduction by $\mathrm{Fe}^{0}$ and indirect reduction by hydrogen formed via acidic corrosion of iron contribute to nitrate removal [14]. Some investigations have shown that nitrate reduction by iron powder only occurs at low $\mathrm{pH}(\leq 4)[14,20,21]$, in which acid dissolves the passive oxide layers on iron to maintain a fresh surface, and the redox reaction between nitrate and $\mathrm{Fe}^{0}$ occurs continuously. In contrast, a negligible nitrate reduction is observed at higher initial $\mathrm{pH}(>5)$ [14] or in unbuffered solutions $[13,18,20]$. The rate of nitrate reduction at initial $\mathrm{pH}$ of 
5.5 buffered by 4-morpholineethanesulfonic (MES) has been demonstrated to be faster by two orders than that at initial $\mathrm{pH}$ of 9.0 buffered by $\mathrm{N}$-(tris(hydroxymethyl)methyl)-3aminopro-panesulfonic acid (TAPS) [10]. Additionally, trace amounts of nitrite indeed accumulate as intermediate in the system at final $\mathrm{pH}$ of $7.5-9.0[19,22]$. Huang and Zhang [21] have indicated that high effects of $\mathrm{pH}$ on the reduction of nitrate by $\mathrm{Fe}^{0}$ can be attributed to: (1) $\mathrm{H}^{+}$ions are directly involved in the nitrate reduction; (2) $\mathrm{H}^{+}$ions affect the nitrate adsorption onto reactive sites of iron surface and (3) the formation rates and the compositions of the oxide layers are highly depended on the solutions $\mathrm{pH}$. Ritter et al. [25] have used an in situ, non-destructive technique, Raman spectroscopy, to identify the formation of high valency of oxide layers and its interaction with nitrate. Goethite $(\gamma-\mathrm{FeOOH})$, lepidocrocite $(\alpha-\mathrm{FeOOH})$, magnetite $\left(\mathrm{Fe}_{3} \mathrm{O}_{4}\right)$ and $\mathrm{Fe}_{2} \mathrm{O}_{3}$ are observed as constituents of the passive layers formed on iron surface in nitrate-containing solutions. The potential and $\mathrm{pH}$ conditions thermodynamically control the formation of oxide layers during nitrate reduction [6]. Both iron oxidation and nitrate reduction reactions consume acidity, resulting in an initially rapid $\mathrm{pH}$ rise without acidification [20]. Continuous addition of acid or buffering via weak acid is needed to maintain favorable reducing condition and reaction rate. The $\mathrm{pH}$ control, however, restricts the practical applications of zero valent iron. An enhanced method without the addition of acidic or buffer solution is necessary for the treatment of nitrate in groundwater commonly observed at near neutral $\mathrm{pH}$.

$\mathrm{Fe}^{0}$ particles with dimensions in the range $1-100 \mathrm{~nm}$ (nano-Fe ${ }^{0}$ ) possess the advantages of larger specific surface area and higher surface reactivity over microscale $\mathrm{Fe}^{0}$ to increase the chemical reduction rate of halogenated organic compounds. Increase in surface area normalized rates by 1-3 orders of magnitude has been reported in TCE or $\mathrm{CCl}_{4} /$ nano$\mathrm{Fe}^{0}$ /water system [26-29]. Further enhancement of reactivity is obtained by coating small amount of less active metal (e.g. $\mathrm{Pd}, \mathrm{Pt}, \mathrm{Ni}$ and $\mathrm{Cu}$ ) onto the freshly prepared nano- $\mathrm{Fe}^{0}$ surface due to the promotion of iron oxidation by the potential difference [30-32]. In the dehalogenation reactions with bimetallic nanoparticles, the formation of toxic by-products is prevented, and the yields of benign products are increased [28,30-32]. So, reducing the size of reductants into nanoscale would obtain some advantages, including: (1) an increase in reductive degradation reaction rate, (2) a decrease of reductants dosage and (3) control over the risk of toxic intermediates release. Nanoparticles can be anchored onto a solid matrix for treatment of water, wastewater and gaseous steams [9]. Additionally, direct subsurface injection of iron nanoparticles to effectively degrade chlorinated organic compounds has been demonstrated [31]. The technology provides enormous flexibility for in situ or ex situ remediation.

Zhang and his co-workers [26-29] have extensively demonstrated that in the laboratory studies and field tests various halogenated hydrocarbons can be rapidly reduced to benign hydrocarbons by nano- $\mathrm{Fe}^{0}$ particles. Unlike halo- genated hydrocarbon reduction, nitrate reduction by $\mathrm{Fe}^{0}$ is relatively sensitive to the solution $\mathrm{pH}$, and nitrate is well known as an oxidizing inhibitor to iron corrosion due to the formation of an overlying oxide layer. Except for the study of Choe et al. [33], the removal of nitrate from unbuffered water at initial neutral $\mathrm{pH}$ by nano- $\mathrm{Fe}^{0}$ has been relatively few reported. In this study, nano- $\mathrm{Fe}^{0}$ and nano-bimetals were synthesized to evaluate the kinetics of the denitrification reactions. Additionally, attention was also given to the reaction mechanisms through both the investigation of kinetic control and the identification of the reaction products and intermediates.

\section{Material and methods}

\subsection{Chemicals}

Potassium nitrate and sodium nitrite were purchased from Aldrich (>99\%, Milwaukee, WI). The microscale zero valent iron used (99.6\%, finer than 100 mesh) was obtained from J.T. Baker. Nessler's Reagent (Fluka) was used for ammonia measurement. Copper precursors, copper(II) chloride, were supplied by Alfa. All other chemicals used in this work were analytical reagent grade and solutions were prepared in water purified with a Milli-Q ${ }^{\mathrm{TM}}$ system $\left(18.2 \mathrm{M} \Omega \mathrm{cm}^{-1}\right)$.

\subsection{Manufacture and characterization of nano- $\mathrm{Fe}^{0}$ and nano-Cu/Fe particles}

In a nano- $\mathrm{Fe}^{0}$ particle synthesis, $\mathrm{NaBH}_{4}(98 \%$, Aldrich) solution was added carefully into $1.0 \mathrm{M} \mathrm{FeCl}_{3} \cdot 6 \mathrm{H}_{2} \mathrm{O}$ (98\%, Aldrich) aqueous solution at ambient temperature as described by Wang and Zhang [26]. Then, ferric iron was reduced into black particles. After the reduction process, the freshly prepared particles were dried in a flow of $\mathrm{H}_{2} / \mathrm{N}_{2}$ $\left(20 \mathrm{vol} \%, 100 \mathrm{~mL} \mathrm{~min}^{-1}\right)$ at $150^{\circ} \mathrm{C}$ for $24 \mathrm{~h}$, then cooled down to room temperature and stored in the reducing gas atmosphere.

Bimetallic particles were prepared by mixing the solution of copper precursor with the freshly prepared nano- $\mathrm{Fe}^{0}$ particles, similar to the previous study [27,32]. The deposition of copper onto the surface of iron, $\mathrm{Cu}$ bulk loading of 0.5 , 5.0, 10.0 and $20.0 \%(\mathrm{w} / \mathrm{w})$, occurred through the following redox reaction:

$\mathrm{Fe}^{0}+\mathrm{Cu}^{2+} \rightarrow \mathrm{Fe}^{2+}+\mathrm{Cu}^{0}$

The procedure was as follows. The desired amount of $1000 \mathrm{mg}-\mathrm{Cu} / \mathrm{L} \mathrm{CuCl} \mathrm{Cu}_{2}$ aqueous solution was added to nano$\mathrm{Fe}^{0}$ in a bottle. After 5 min of redox reaction between the $\mathrm{Cu}^{2+}$ and nano- $\mathrm{Fe}^{0}$, the resulting nano- $\mathrm{Cu} / \mathrm{Fe}$ particles were washed twice with Milli- $\mathrm{Q}^{\mathrm{TM}}$ water. The drying process and storage method followed the above description.

Surface areas of the nanosized iron and powdered iron particles were measured using nitrogen adsorption method 
with an ASAP 2010 surface analyzer. Hitachi H-7100 transmission electron microscopy (TEM) was used to characterize the size of the metal particles. The localized elemental information from the chosen region of iron particles were viewed with energy disperse X-ray spectroscopy (EDX) in conjunction with scanning electron microscopy (SEM).

\subsection{Batch experiment with $\mathrm{NO}_{3}{ }^{-}$}

All experiments as function of time were performed with $75 \mathrm{~mL}$ serum bottles. A solution with $\mathrm{pH}$ of $6.5 \pm 0.3$ and $\mathrm{CaCO}_{3}$ concentration of $1.2 \times 10^{-3} \mathrm{M}$ was preparedmand purged with argon [34]. A $75 \mathrm{~mL}$ sample of $40 \mathrm{mg} \mathrm{N} \mathrm{L}^{-1}$ nitrate from the simulated groundwater and $0.0265 \mathrm{~g}$ of uncatalyzed and catalyzed nano- $\mathrm{Fe}^{0}$ were added into a $75 \mathrm{~mL}$ plastic bottle. The bottles were sealed with parafilm and mixed at $200 \mathrm{rpm}$ using a reciprocal shaker water bath (Yihder, BT-350R) without $\mathrm{pH}$ control. The samples were taken at certain time intervals and filtered immediately using a Milipore filter ( $25 \mathrm{~mm}$ diameter, $0.2 \mu \mathrm{m}$ pore size). Filtrates were collected and analyzed immediately. Nitrate and nitrite were measured using an ion chromatograph (Model: Dionex-100) with a column of IonPac AS4A-SC $(4.0 \mathrm{~mm} \times 4.0 \mathrm{~mm}$ i.d.). A mixed solution of $1.7 \mathrm{mM} \mathrm{Na}_{2} \mathrm{CO}_{3}$ and $1.8 \mathrm{mM} \mathrm{NaHCO}_{3}$ was used as the mobile phase at a flow rate of $1.0 \mathrm{~mL} \mathrm{~min}^{-1}$. Ammonium was analyzed by indophenol method [35] using a spectrometer (UV Spctronic 20 Genesys). All experiments were duplicated and the averaged results were presented.

\section{Results and discussions}

\subsection{Nitrate reduction by microscale and nanoscale $\mathrm{Fe}^{0}$}

The residual fraction of nitrate of $75 \mathrm{~mL}$ simulated groundwater containing $40 \mathrm{mg} \mathrm{N} \mathrm{L}^{-1}$ nitrate with $0.0265{\mathrm{~g} \text { nano- }-\mathrm{Fe}^{0}}^{0}$ particles and $1.0 \mathrm{~g}$ powdered $\mathrm{Fe}^{0}$ (at $25^{\circ} \mathrm{C}$ ) is shown in Fig. 1 . Removal of nitrate by nano- $\mathrm{Fe}^{0}$ particles began with initial nitrate mass decreasing by $52 \%$ within $60 \mathrm{~min}$ (Fig. 1), and the $\mathrm{pH}$ rising rapidly from an initial value of $6.8-10.0$ and then leveling off (data not shown); meanwhile, a small amount of nitrate removal (about 3\%) and small pH change (from 6.8 to 7.6) were observed using microscale $\mathrm{Fe}^{0}$.

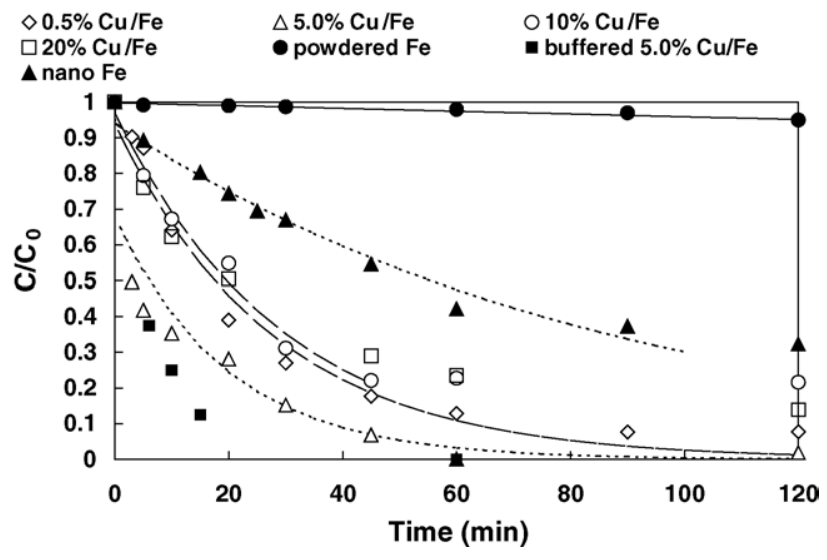

Fig. 1. Kinetics of nitrate removal as function of reaction time in the presence of various reductive materials at $25^{\circ} \mathrm{C}$.

The nitrate reduction curves were fitted to a single exponential to obtain the pseudo-first-order reaction rate constant, $k_{\text {obs }}\left(R^{2}>0.94\right)$. As shown in Table 1 , nano- $\mathrm{Fe}^{0}$ and microscale $\mathrm{Fe}^{0}$ particles have the $k_{\text {obs }}$ values of 1.37 and $0.40 \times 10^{-2} \mathrm{~min}^{-1}$, respectively. Generally, the nitrate reduction rate is proportional to exposed iron surface area. Therefore, regarding the iron activity per unit surface area, the $k_{\text {obs }}$ will necessarily normalize according to the surface area and the mass concentration of iron particles. The surface area normalized rate constant $\left(k_{\mathrm{SA}}\right)$ can be calculated by Eq. (2).

$k_{\mathrm{SA}}=\frac{k_{\mathrm{obs}}}{\rho_{\mathrm{a}}}$

where $\rho_{\mathrm{a}}$ is the surface area concentration of $\mathrm{Fe}^{0}$ in $\mathrm{m}^{2} \mathrm{~L}^{-1}$ and $k_{\mathrm{SA}}$ is a parameter of assessment of the overall surface reactivity. The BET surface areas are $16.67 \mathrm{~m}^{2} \mathrm{~g}^{-1}$ for nano$\mathrm{Fe}^{0}$ and $0.56 \mathrm{~m}^{2} \mathrm{~g}^{-1}$ for microscale $\mathrm{Fe}^{0}$. As expected, the specific surface area increases with decreasing particle size. The value of $\rho_{\mathrm{a}}$ is $5.89 \mathrm{~m}^{2} \mathrm{~L}^{-1}$ for nano- $\mathrm{Fe}^{0}$ particles and $7.47 \mathrm{~m}^{2} \mathrm{~L}^{-1}$ for microscale $\mathrm{Fe}^{0}$ in the batch experiments. Thus, the $k_{\mathrm{SA}}$ for microscale $\mathrm{Fe}^{0}$ and nano- $\mathrm{Fe}^{0}$ were 0.54 and $23.26 \times 10^{-4} \mathrm{~L} \mathrm{~min}^{-1} \mathrm{~m}^{-2}$, respectively, where nano$\mathrm{Fe}^{0}$ particles reduced nitrate about 40 times faster than did microscale $\mathrm{Fe}^{0}$. The reactivity of nano- $\mathrm{Fe}^{0}$ particles surface was higher relative to microscale $\mathrm{Fe}^{0}$ as indicated by a larger $k_{\mathrm{SA}}$ for nano- $\mathrm{Fe}^{0}$ even at more alkaline conditions.

Table 1

The specific surface area, pseudo-first-order rate constant and surface area normalized rates for various reductants at $25^{\circ} \mathrm{C}$

\begin{tabular}{|c|c|c|c|}
\hline Reductants & BET area $\left(\mathrm{m}^{2} \mathrm{~g}^{-1}\right)$ & $k_{\mathrm{obs}}\left(10^{-2} \mathrm{~min}^{-1}\right)$ & $k_{\mathrm{SA}}\left(10^{-4} \mathrm{~L} \mathrm{~min}^{-1} \mathrm{~m}^{-2}\right)$ \\
\hline Microscale $\mathrm{Fe}^{0}$ & 0.56 & 0.04 & 0.54 \\
\hline Nano-Fe ${ }^{0}$ & 16.67 & 1.37 & 23.26 \\
\hline Nano-Cu/Fe $(0.5 \%, w / w)$ & - & 3.73 & - \\
\hline Nano-Cu/Fe $(5.0 \%$, w/w) & - & 4.93 & - \\
\hline Nano-Cu/Fe (10\%, w/w) & - & 3.09 & - \\
\hline Nano-Cu/Fe $(20 \%, w / w)$ & - & 2.07 & - \\
\hline Buffered, nano-Cu/Fe $(5.0 \%, w / w)$ & - & 14.06 & - \\
\hline Regenerated nano- $\mathrm{Fe}^{0}$ & 14.51 & 1.15 & 22.46 \\
\hline Regenerated nano-Cu/Fe $(5.0 \%, w / w)$ & - & 3.70 & - \\
\hline
\end{tabular}




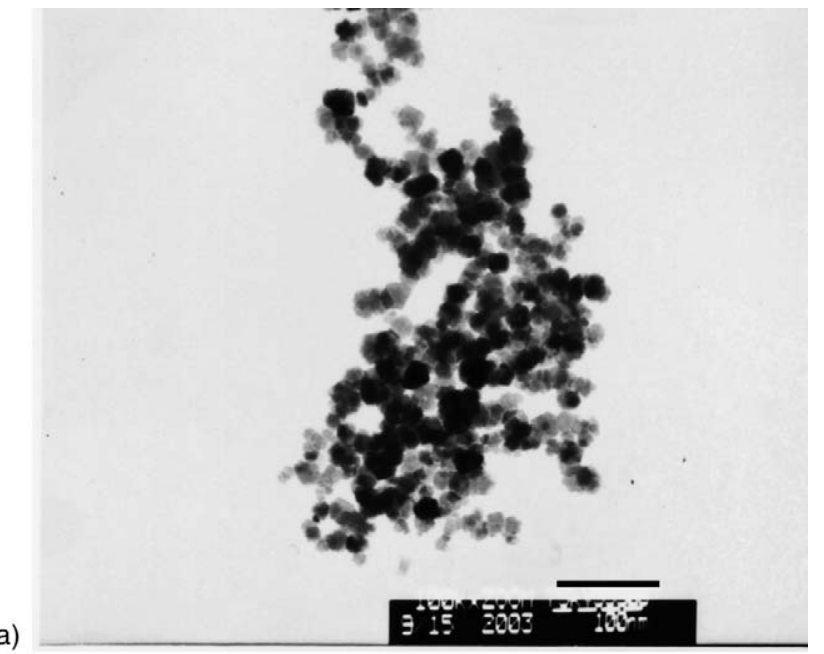

(a)

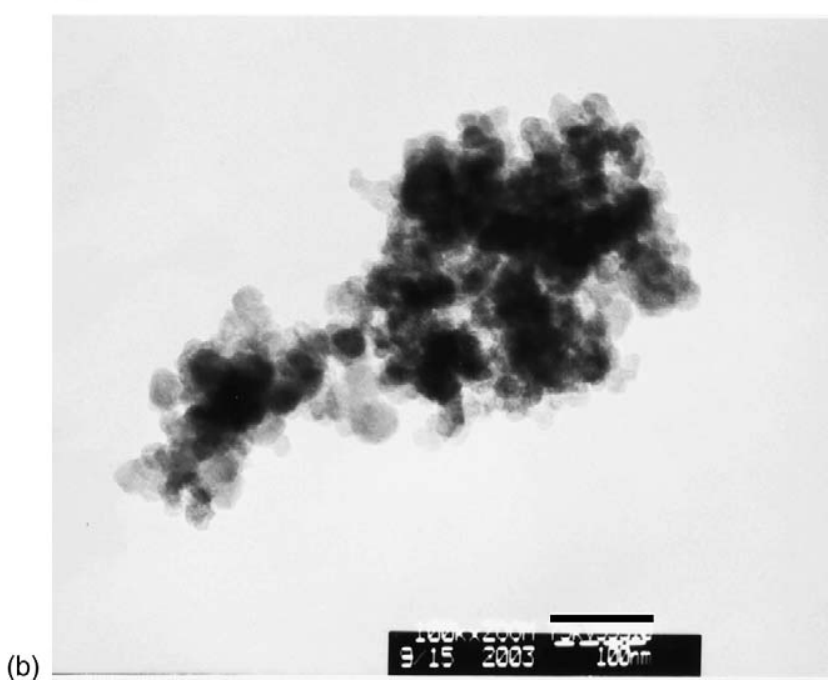

Fig. 2. Transmission electron microscopy image of (a) fresh nano- $\mathrm{Fe}^{0}$ particles and (b) regenerated nano- $\mathrm{Fe}^{0}$ particles with a magnification of 100,000 .

After nano- $\mathrm{Fe}^{0}$ was soaked in simulated groundwater containing $40 \mathrm{mg} \mathrm{N} \mathrm{L}^{-1}$ nitrate for 2 days, the aged nano- $\mathrm{Fe}^{0}$ was regenerated by adding $\mathrm{NaBH}_{4}$ solution and then was dried in a flow of $\mathrm{H}_{2} / \mathrm{N}_{2}\left(20 \mathrm{vol} \%, 100 \mathrm{~mL} \mathrm{~min}^{-1}\right)$ at $150{ }^{\circ} \mathrm{C}$ for $24 \mathrm{~h}$. Compared with the freshly prepared nano- $\mathrm{Fe}^{0}$, the $k_{\text {obs }}$ of nitrate reduction by the regenerated nano- $\mathrm{Fe}^{0}$ with the specific surface area of $14.51 \mathrm{~m}^{2} \mathrm{~g}^{-1}$ was recovered at the level of about $85 \%\left(k_{\mathrm{obs}}, 1.15 \times 10^{-2} \mathrm{~min}^{-1}\right)$. Fig. 2 is the images of both fresh and regenerated nano- $\mathrm{Fe}^{0}$ particles obtained by TEM with a magnification of 100,000. Most fresh nano- $\mathrm{Fe}^{0}$ particles had diameters in the range of $10-40 \mathrm{~nm}$ (Fig. 2a), whereas the regenerated nano- $\mathrm{Fe}^{0}$ particles are relatively wide in size distribution $(20-70 \mathrm{~nm})$ (Fig. 2b). The $k_{\text {obs }}$ value for regenerated nano- $\mathrm{Fe}^{0}$ was decreased due to the aggregation of nano- $\mathrm{Fe}^{0}$ particles. However, the $k_{\mathrm{SA}}$ value of $23.26 \times 10^{-4} \mathrm{~L} \mathrm{~min}^{-1} \mathrm{~m}^{-2}$ for fresh nano-Fe ${ }^{0}$ was remarkably similar to the value of $22.46 \times 10^{-4} \mathrm{~L} \mathrm{~min}^{-1} \mathrm{~m}^{-2}$ for regenerated nano- $\mathrm{Fe}^{0}$. The result indicates the regeneration process completely restored $k_{\mathrm{SA}}$ values but generally decreased $k_{\text {obs }}$ values due to the decrease in the exposure surface area per unit mass of nano- $\mathrm{Fe}^{0}$.

\subsection{Deposition of the second metal}

Three noble metal including $\mathrm{Pd}, \mathrm{Pt}$ and $\mathrm{Cu}$ were separately deposited onto nano- $\mathrm{Fe}^{0}$ surface for testing their reactivity to nitrate reduction. In these cases, $0.0265 \mathrm{~g}$ of $5.0 \%(\mathrm{w} / \mathrm{w}$ ) bimetal particles (nano-Pd/Fe, nano-Pt/Fe and nano- $\mathrm{Cu} / \mathrm{Fe}$ ) was added to Ar-purged buffered $40 \mathrm{mg} \mathrm{N} \mathrm{L}^{-1}$ nitrate solution in $75 \mathrm{~mL}$ serum bottles. In the nano- $\mathrm{Pd} / \mathrm{Fe}$ and nano-Pt/Fe systems, the $k_{\text {obs }}$ values were $1.69 \times 10^{-2} \mathrm{~min}^{-1}$ for nano-Pd/Fe and $1.73 \times 10^{-2} \mathrm{~min}^{-1}$ for nano-Pt/Fe, slightly accelerating the rate of nitrate reduction as compared to nano- $\mathrm{Fe}^{0}\left(1.37 \times 10^{-2} \mathrm{~min}^{-1}\right)$. When copper was deposited onto the nano- $\mathrm{Fe}^{0}$ surface, the $k_{\mathrm{obs}}$ increased to be $4.93 \times 10^{-2} \mathrm{~min}^{-1}$. The deposited metals were ranked $\mathrm{Cu}>\mathrm{Pd}>\mathrm{Pt}$ in their promotion on nano- $\mathrm{Fe}^{0}$ reactivity toward nitrate. Hence, copper was chosen as a second metal at the further experiments.

The deposition of various amounts of copper onto the nano- $-\mathrm{Fe}^{0}$ particles surface $(0.5,5.0,10.0$ and $20.0 \%$, w/w) to reduce $40 \mathrm{mg} \mathrm{N} \mathrm{L}^{-1}$ nitrate in simulated groundwater at $25^{\circ} \mathrm{C}$ was evaluated. As expected, the nano- $\mathrm{Cu} / \mathrm{Fe}$ particles exhibited more efficient and rapid nitrate removal than nano$\mathrm{Fe}^{0}$ particles (Fig. 1). The nitrate reduction curves were fitted to a signal exponential to obtain $k_{\text {obs }}$ (the data at the first $45 \mathrm{~min}$ of the reaction were used for 10 and $20 \%$ nano- $\mathrm{Cu} / \mathrm{Fe}$, and all of the data within $120 \mathrm{~min}$ were used for 0.5 and $5.0 \%$ nano- $\mathrm{Cu} / \mathrm{Fe}$ ). The $k_{\mathrm{obs}}$ values are 3.73, 4.93, 3.09 and $2.07 \times 10^{-2} \mathrm{~min}^{-1}$ for $0.5,5.0,10$ and $20 \%$ copper loading, respectively. At the end of the experiment (120 min), 92, 100,86 and $78 \%$ removal of initial nitrate mass were obtained for $0.5,5.0,10$ and $20 \%$ copper loading, respectively. These results exhibited a rising reactivity with an increased content of copper up to $5.0 \%$; the maximum promoted rate with $5.0 \%$ nano- $\mathrm{Cu} / \mathrm{Fe}$ particles was 3.6 times that of nano- $\mathrm{Fe}^{0}$ particles on a mass basis. A further increase of the copper loadings did not continue to increase the removal rate. In addition, iron and copper play different roles in the course of denitrification reaction. Thus, it is not essential to normalize $k_{\mathrm{obs}}$, unless the individual surface areas of bimetallic particles are distinguished [36].

The ratio of two metals in bimetallic particles is crucial for its reactivity toward target pollutants reduction [37]. An additional experiment using SEM/EDX to view the dispersion degree of copper particles on iron surface was examined. Instead of nano- $\mathrm{Cu} / \mathrm{Fe}$, an equivalent loading on the surface of powdered iron, normalized by specific surface area, was viewed due to the limit of analytic technique. One gram of powdered iron with $0.56 \mathrm{~m}^{2} \mathrm{~g}^{-1}$ were separately deposited $0.017,0.168$ and $0.672 \mathrm{~g}$ of copper, approximately equal to $0.5,5.0$ and $20 \%$ of copper loading on nano- $\mathrm{Fe}^{0}$ particles with $16.67 \mathrm{~m}^{2} \mathrm{~g}^{-1}$. EDX mappings of copper elements show a high degree of dispersion from equivalent 0.5 to $5.0 \%$, and a low degree of dispersion at equivalent $20 \%$ (Fig. 3). Con- 

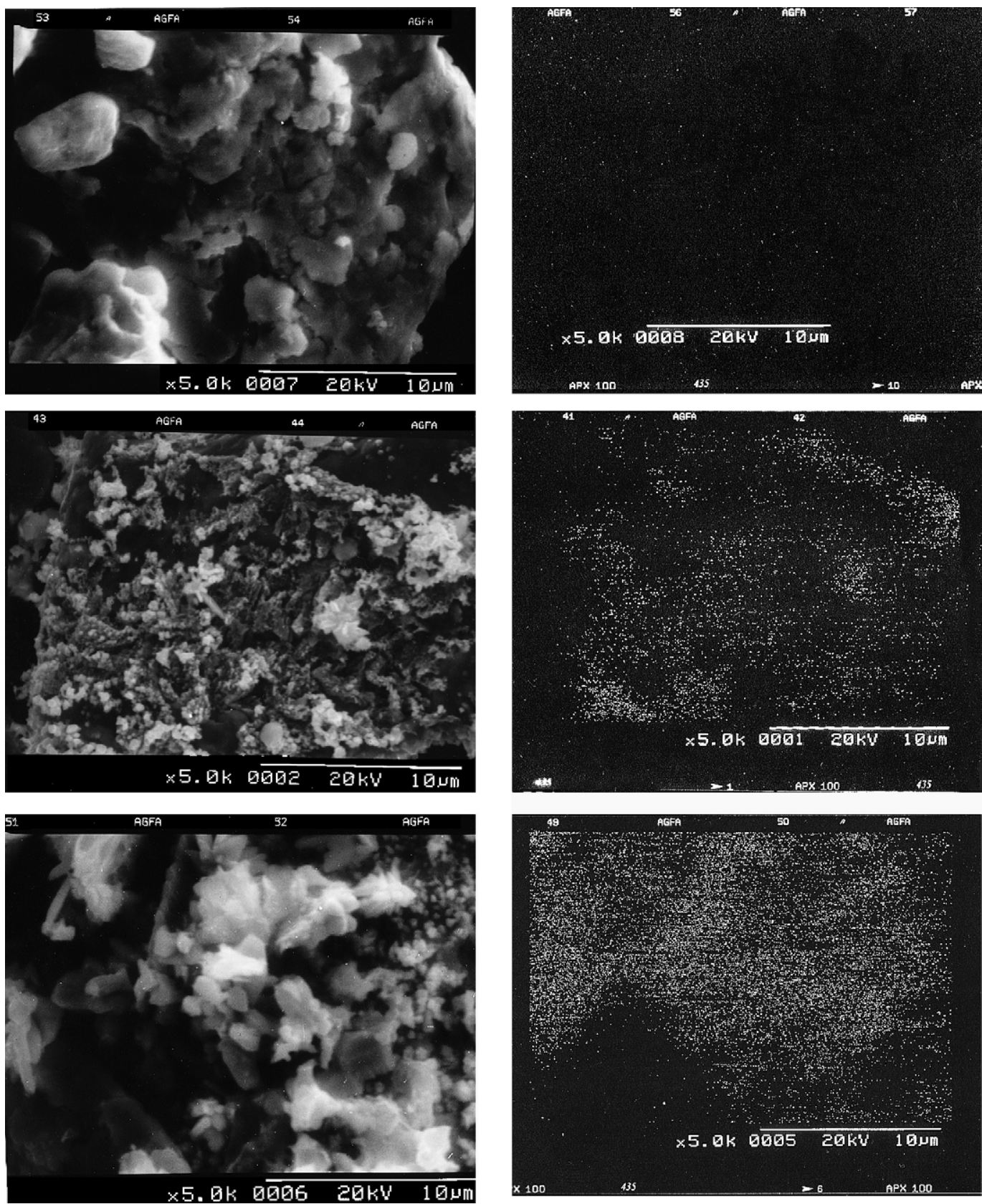

Fig. 3. Mapping of bimetal particles with various copper loading (a) equivalent $0.5 \% \mathrm{Cu} / \mathrm{Fe}$, (b) equivalent $5.0 \% \mathrm{Cu} / \mathrm{Fe}$ and (c) equivalent $20.0 \% \mathrm{Cu} / \mathrm{Fe}$. The spots with high contrast indicated the density of copper elements on $\mathrm{Cu} / \mathrm{Fe}$ particles.

sequently, excess amounts of copper loading led to a high degree of copper particle agglomeration and a low exposure of iron surface area in water with led to a negative effect on the initial reaction reactivity.

The reduction efficiency of the system with $10 \%$ nano$\mathrm{Cu} / \mathrm{Fe}(78 \%)$ is indeed slightly lower than that of the system with $20 \%$ nano- $\mathrm{Cu} / \mathrm{Fe}(86 \%)$, even though initially the $k_{\text {obs }}$ value of $10 \%$ nano- $\mathrm{Cu} / \mathrm{Fe}$ was higher than that of $20 \%$ nano$\mathrm{Cu} / \mathrm{Fe}$. One process might account for these results is the transport of $\mathrm{Fe}^{2+}$ out of the $\mathrm{Cu} / \mathrm{Fe}$ cavity. The precipitation of passivating iron oxide, clogging the cavity pore space, dominated the nitrate reaction by restricting the mass transport of $\mathrm{Fe}^{2+}$. The stagnation of the reaction in $10 \%$ nano- $\mathrm{Cu} / \mathrm{Fe}$ system occurred earlier than that in $20 \%$ nano-Cu/Fe (Fig. 1). Thus, the larger reaction efficiency of the system with $20 \%$ nano- $\mathrm{Cu} / \mathrm{Fe}$ than that with $10 \%$ nano- $\mathrm{Cu} / \mathrm{Fe}$ was observed at the end of the experiment.

The regeneration experiment was performed on 5.0\% nano- $\mathrm{Cu} / \mathrm{Fe}$ particles with continual soaking in nitrate solution for 2 days. The aged $5.0 \%$ nano- $\mathrm{Cu} / \mathrm{Fe}$ was reduced by adding $\mathrm{NaBH}_{4}$ powder and then was dried in a flow of $\mathrm{H}_{2} / \mathrm{N}_{2}$ $\left(20 \mathrm{vol} \%, 100 \mathrm{~mL} \mathrm{~min}^{-1}\right)$ at $150^{\circ} \mathrm{C}$ for $24 \mathrm{~h}$. Before regenerating, the $k_{\mathrm{obs}}$ value of $1.48 \times 10^{-2} \mathrm{~min}^{-1}$ for the aged nano- $\mathrm{Cu} / \mathrm{Fe}$ particles decreased about to $30 \%$ that of the fresh 
$5.0 \%$ nano- $\mathrm{Cu} / \mathrm{Fe}$ particles. After the regeneration process, the $k_{\text {obs }}$ value rose to $3.70 \times 10^{-2} \mathrm{~min}^{-1}$. About $75 \%$ of the reactivity was recovered for $0.5 \%$ nano- $\mathrm{Cu} / \mathrm{Fe}$ particles. After the regeneration process, the loose iron oxides converted into dense zero valence and impeded the exposure of copper into the solution. Due to a rising reactivity with an increased content of copper up to $5.0 \%$, the decrease in the exposure of copper resulted in a loss of about $25 \%$ of the reactivity.

\subsection{Temperature effect}

Temperature is important in providing some insight into the reaction mechanisms [38,39]. A process limited by mass transport should show little influence of temperature, whereas controlled by chemical reaction is often sensitive to a change in temperature. The rates of nitrate reduction by microscale $\mathrm{Fe}^{0}$, nano- $\mathrm{Fe}^{0}$ and nano- $\mathrm{Cu} / \mathrm{Fe}$ measured in batch experiments exhibited a temperature dependency consistent with the Arrhenius equation:

$k_{\mathrm{obs}}=A \exp \frac{-E_{\mathrm{a}}}{R T}$

where $E_{\mathrm{a}}$ is the activation energy $\left(\mathrm{kJ} \mathrm{mol}^{-1}\right), A$ preexponential factor $\left(\mathrm{min}^{-1} \mathrm{~m}^{-2} \mathrm{~L}\right), R$ the molar gas constant $\left(0.008314 \mathrm{~kJ} \mathrm{~mol}^{-1} \mathrm{~K}^{-1}\right)$ and $T$ is the absolute temperature (K). The activation energy for the reaction was obtained from the slope of a plot of $\ln \left(k_{\mathrm{obs}}\right)$ versus $1 / T$ using linear leastsquare analysis (Table 2).

In this case, the $E_{\mathrm{a}}$ is a measure of the energy required to complete the reduction of nitrate and oxidation of $\mathrm{Fe}^{0}$. Several steps, including nitrate diffusion and adsorption onto iron, chemical reaction on the iron surface, and products diffusion into the solution, were involved in the overall reaction. The slowest reaction step with the greatest $E_{\mathrm{a}}$ determines the kinetics of a reaction. Diffusion requires less energy than chemical reaction. A typical mass transport-controlled reaction in water was considered $10-20 \mathrm{~kJ} \mathrm{~mol}^{-1}$, which was cited most often [38-40]. In this study, the nitrate reduction in batch experiments using microscale $\mathrm{Fe}^{0}$ gave $E_{\mathrm{a}}=42.5$ and $25.8 \mathrm{~kJ} \mathrm{~mol}^{-1}$ for nano- $\mathrm{Fe}^{0}$ and $E_{\mathrm{a}}=16.8 \mathrm{~kJ} \mathrm{~mol}^{-1}$ for nano$\mathrm{Cu} / \mathrm{Fe}$ over the temperature range of $10-60^{\circ} \mathrm{C}$ (Table 2). The value of $E_{\mathrm{a}}$ for microscale $\mathrm{Fe}^{0}$ was large enough to consider being a typical of the chemical reaction step. Thus, there is a significant degree of reaction control on the kinetics of denitrification in a well-mixed microscale $\mathrm{Fe}^{0}$ system. However, as the $E_{\mathrm{a}}$ for nano- $\mathrm{Fe}^{0}$ with a value slightly above $10-20 \mathrm{~kJ} \mathrm{~mol}^{-1}$ and that for nano-Cu/Fe less than
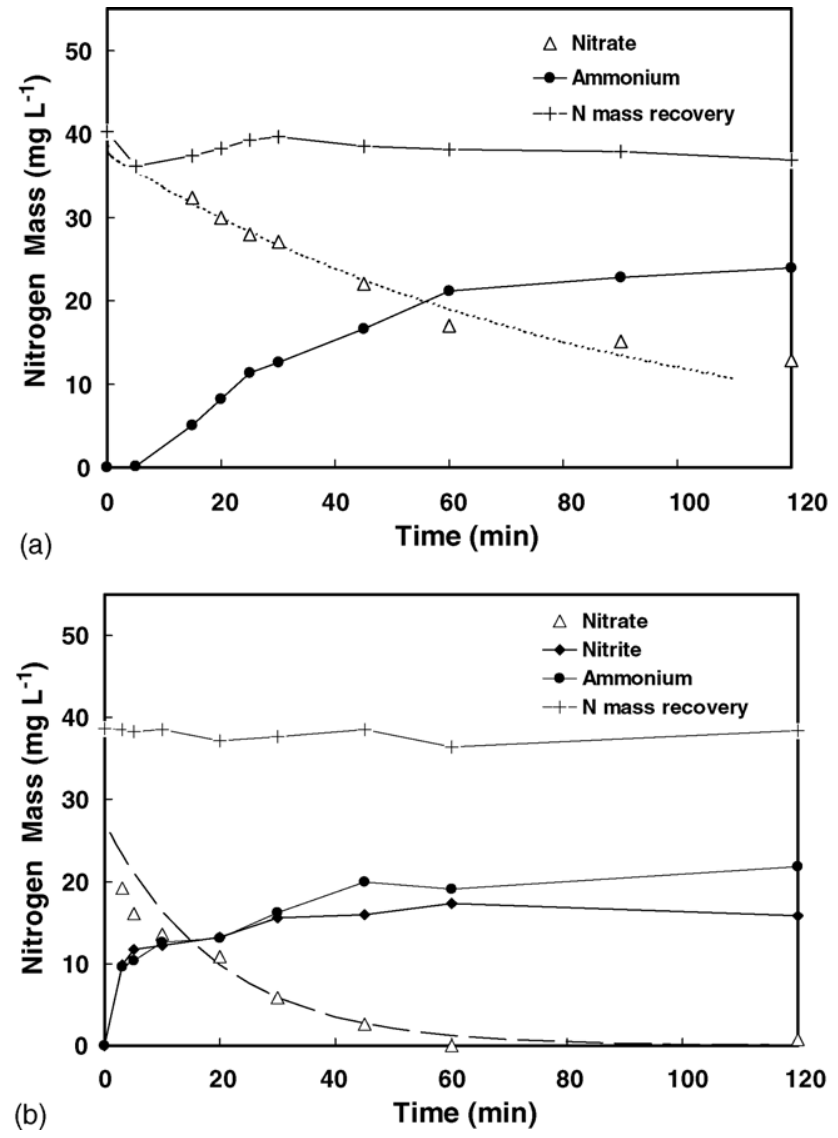

Fig. 4. Kinetics and by-products of $40 \mathrm{mg} \mathrm{N} \mathrm{L}^{-1}$ nitrate reduction with (a) $0.0265 \mathrm{~g}$ nano- $\mathrm{Fe}^{0}$ particles and (b) $0.0265 \mathrm{~g} \mathrm{5.0 \%}$ nano- $\mathrm{Cu} / \mathrm{Fe}$ particles at $25^{\circ} \mathrm{C}$.

$20 \mathrm{~kJ} \mathrm{~mol}^{-1}$, the kinetics of denitrification began to show characteristics of mass transport in addition to reaction control.

\subsection{Intermediates and final products}

In reaction with nano- $\mathrm{Fe}^{0}$ particles, ammonium accounted for above $95 \%$ of the degraded nitrate, and no detectable amount of nitrite (the detect limit, $0.1 \mathrm{mg} \mathrm{N} \mathrm{L}^{-1}$ ) was observed (Fig. 4a). The nitrite generations from incomplete nitrate reduction by $\mathrm{Fe}^{0}$ are neither observed in the experiments at low or near neutral $\mathrm{pH}$ with buffering [13-15,20,21], whereas trace amounts of nitrite indeed accumulate as intermediate in the system at final $\mathrm{pH}$ of $7.5-9.0[19,22]$. Alowitz and Scherer [10] have chosen five organic buffers to ade-

Table 2

Activation energies for nitrate reduction by microscale $\mathrm{Fe}^{0}$, nano- $\mathrm{Fe}^{0}$ and $5.0 \%$ nano- $\mathrm{Cu} / \mathrm{Fe}$ (calculated from all four temperature data)

\begin{tabular}{llllll}
\hline Reductants & \multicolumn{2}{l}{ Pseudo-first-order rate constants $\left(10^{-2} \mathrm{~min}^{-1}\right)$} & \multirow{2}{*}{${\text { Activation energy }\left(\mathrm{kJ} \mathrm{mol}{ }^{-1}\right)}^{\circ}$} \\
\cline { 2 - 5 } & $10^{\circ} \mathrm{C}$ & $25^{\circ} \mathrm{C}$ & $40^{\circ} \mathrm{C}$ & $60^{\circ} \mathrm{C}$ & 42.5 \\
\hline Microscale $\mathrm{Fe}^{0}$ & 0.02 & 0.04 & 0.11 & 0.22 & 25.8 \\
Nano-Fe $^{0}$ & 0.75 & 1.37 & 1.66 & 4.26 & 16.8 \\
$5 \% \mathrm{Nano}-\mathrm{Cu} / \mathrm{Fe}$ & 2.91 & 4.93 & 6.90 & 8.51 & \\
\hline
\end{tabular}




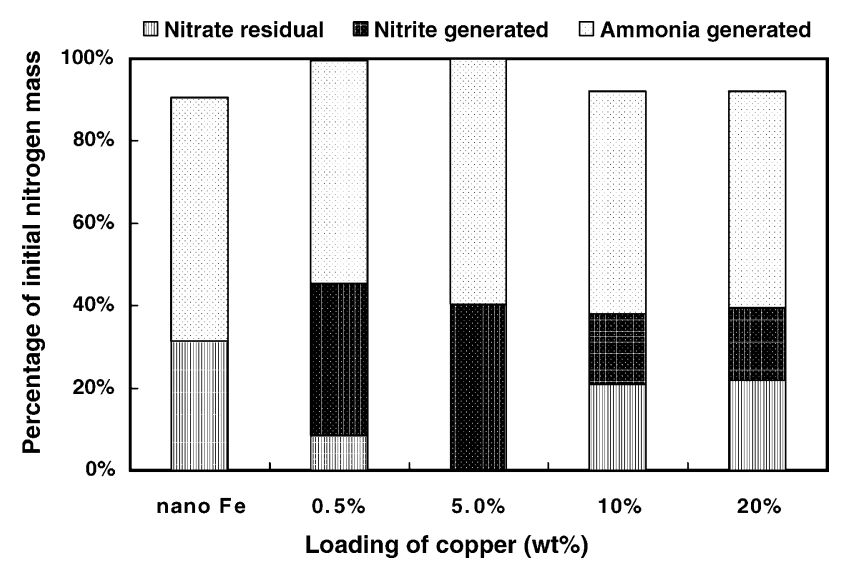

Fig. 5. Nitrogen mass balance of the sum of nitrate, nitrite and ammonia/ammonium at steady state $(120 \mathrm{~min})$.

quately maintain the initial $\mathrm{pH}$ at the range of 5.5-9.0. The reduction rates of nitrite are much higher than that of nitrate at the $\mathrm{pH}$ range of 5.5-7.0, and the rates decrease with increasing $\mathrm{pH}$ with apparent reaction orders of about 0.6 for nitrite and 0.5 for nitrate. At the $\mathrm{pH}$ range of 7.5-8.5, similar reduction rate for nitrite and nitrate are observed. At $\mathrm{pH}$ 9.0, however, negligible nitrite reduction is observed over $48 \mathrm{~h}$, but measurable reduction of nitrate occurs. Rapid nitrite reduction by $\mathrm{Fe}^{0}$ may explain an absence of nitrite accumulation when the solution $\mathrm{pH}$ is low or near neutral $\mathrm{pH}$. However, no detectable amount of nitrite was observed in reactions with nano- $\mathrm{Fe}^{0}$ particles (Fig. 4a), even if the solution $\mathrm{pH}$ was rapidly becoming alkaline (final $\mathrm{pH} 10$ ). Thus, the intermediates were proposed to remains sorbed to the high reactivity surface of nano- $\mathrm{Fe}^{0}$ particle until the formation of ammonium or nitrogen was achieved, similar to the sequential dehalogenation of carbon tetrachloride to methane reported by Matheson and Tratnydk [2].

Fig. 4b shows the concentration profile of nitrate, nitrite and ammonium for the $5 \%$ nano- $\mathrm{Cu} / \mathrm{Fe}$ system. However, as for nitrite, $40 \%$ of the degraded nitrate was released to the solutions. Additionally, Fig. 5 shows considerable amounts of nitrite persisted in each system with nano- $\mathrm{Cu} / \mathrm{Fe}$ particles at about $22-40 \%$ of the degraded nitrate ( $40 \%$ for $0.5 \%$ $\mathrm{Cu} / \mathrm{Fe}, 40 \%$ for $5.0 \% \mathrm{Cu} / \mathrm{Fe}, 22 \%$ for $10 \% \mathrm{Cu} / \mathrm{Fe}$ and $22 \%$ for $20 \% \mathrm{Cu} / \mathrm{Fe}$ ). Obviously, part from the $\mathrm{pH}$ effects, the mechanisms of denitrification with bimetallic particles different to iron alone also needed to be consider. Adsorbed hydrogen atoms $\left(\mathrm{H}_{\mathrm{ads}}\right)$, serving as the reducing agent, are formed via the reduction of protons from water at the second metal surface and reduce a variety of organohalides much faster than direct electron transfer [36,41]. About $89 \%$ of nitrogen mass balance (Fig. 5) is accounted by residual nitrate and ammonium in the system with nano- $\mathrm{Fe}^{0}$. The incomplete mass balance may be attributed to [19] (1) analytical standard error, (2) production of $\mathrm{N}_{2}$ gas and (3) sorption of nitrate/ammonium ion. Similar to the proposition of previous study [42], this study suggests that $\mathrm{N}_{2}$ should account for

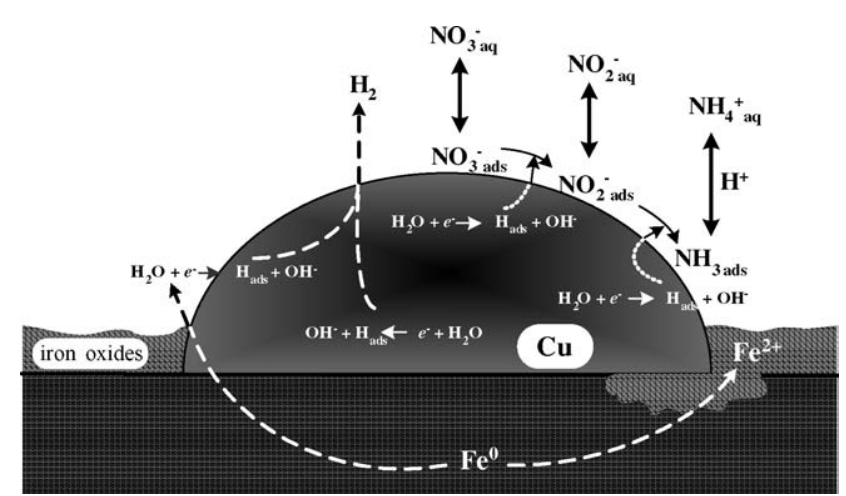

Fig. 6. Proposed scheme of the nitrate reduction reaction at $\mathrm{Cu} / \mathrm{Fe}$ system.

the balance. Almost 100\% mass recovery as residual nitrate, nitrite and ammonium was observed in the system with 0.5 or $5.0 \%$ nano- $\mathrm{Cu} / \mathrm{Fe}$, whereas about $93 \%$ mass recovery was observed in the system with 10 or $20 \%$ nano- $\mathrm{Cu} / \mathrm{Fe}$. This finding indicates that the selectivity toward $\mathrm{N}_{2}$ for nitrate reduction with nano- $\mathrm{Fe}^{0}$ is larger than that with nano- $\mathrm{Cu} / \mathrm{Fe}$. A scheme (Fig. 6) was proposed that nitrate, sorbed to active sites on copper surface, is quickly reduced to nitrite by atomic hydrogen, analogous to that in catalytic nitrate reduction in the presence of hydrogen [43]. Sequentially, the intermediate product, nitrite, is further reduced to the end product ammonia or desorbed into the solution. Here, the high release of the problematic intermediate nitrite is due to its less affinity to copper surface [44].

A separate experiment was conducted using $0.0265 \mathrm{~g}$ of $5.0 \%$ nano- $\mathrm{Cu} / \mathrm{Fe}$ particles to reduce $40 \mathrm{mg} \mathrm{N} \mathrm{L}^{-1}$ nitrate solution at an initial $\mathrm{pH}$ of 7.0 in the presence of $10 \mathrm{mM}$ HEPES buffer which had adequate buffering capacity to maintain the initial $\mathrm{pH}$ (Fig. 1). The denitrification rate was dramatically speeded up approximately 30 times faster than that in the unbuffered solution, and no detectable nitrite was observed in the course of the reaction. Hence, a negligible removal rate of nitrite relative to the rate of the nitrite generation from nitrate transformed at alkaline condition $(\mathrm{pH}$ $>8$ ) led to the accumulation of nitrite. Although nitrite as much as $40 \%$ of the degraded nitrate persisted in the systems with nano- $\mathrm{Cu} / \mathrm{Fe}$, in which the solution $\mathrm{pH}$ has become high alkaline ( $\mathrm{pH} 10)$, nitrite as target pollutant has been found to be easily reduced to nitrogen with a selectivity of $99.9 \%$ at pH 6 by catalytic hydrogenation [45]. Below $10 \% \mathrm{~N}_{2}$ yield was observed when nitrate as target pollutant was reduced by $5.0 \%$ nano-Cu/Fe with buffering (pH 6.5-7.5). Therefore, future research may be considered to stepwise reduce nitrate to nitrite, and then to nitrogen at different $\mathrm{pH}$ for the increase in the selectivity of nitrogen formation.

\section{Conclusions}

In this study, nano- $\mathrm{Fe}^{0}$ and nano- $\mathrm{Cu} / \mathrm{Fe}$ particles were employed for the denitrification of un-buffered $40 \mathrm{mg} \mathrm{NL}^{-1}$ 
nitrate solution at initial neutral $\mathrm{pH}$. The results obtained in this study have demonstrated the following:

(1) The reactivity of nano- $\mathrm{Fe}^{0}$ particles surface was higher than that of microscale $\mathrm{Fe}^{0}$ as indicated by a larger $k_{\mathrm{SA}}$ for nano- $\mathrm{Fe}^{0}$, even at more alkaline conditions. A rising reactivity 3.6 times that of nano- $\mathrm{Fe}^{0}$ particles on a mass basis was observed with an increased content of up to $5.0 \%$.

(2) The $E_{\mathrm{a}}$ value was $42.5 \mathrm{~kJ} \mathrm{~mol}^{-1}$ for microscale $\mathrm{Fe}^{0}$ indicating that chemical reaction rather than diffusion is the predominant process. However, as the $E_{\mathrm{a}}$ values ranged from 16 to $26 \mathrm{~kJ} \mathrm{~mol}^{-1}$ for nano- $\mathrm{Fe}^{0}$ and nano- $\mathrm{Cu} / \mathrm{Fe}$, the kinetics of denitrification began to show characteristics of mass transport in addition to reaction control.

(3) No detectable amount of nitrite was observed in reactions with nano- $\mathrm{Fe}^{0}$, even when the solution $\mathrm{pH}$ was rapidly becoming alkaline (final $\mathrm{pH} 10$ ). The intermediates were proposed to remain sorbed to the high reactivity surface of nano- $\mathrm{Fe}^{0}$ particle until complete transformation to ammonia or nitrogen was achieved.

(4) Considerable amounts of nitrite were released to the solutions in each system with nano- $\mathrm{Cu} / \mathrm{Fe}$ particle at about $22-40 \%$ of the degraded nitrate. Stepwise reduction by atomic hydrogen on the copper surface dominated the nitrate removal, and the accumulation of nitrite resulted from its lower affinity to copper surface and its negligible removal rate at alkaline conditions.

\section{Acknowledgement}

The authors would like to thank the National Science Council of the Republic of China for financially supporting this research under Contract No. NSC 93-2211-E-002-035.

\section{References}

[1] R.W. Gillham, S.F. O'Hannesin, Enhanced degradation of halogenated aliphatics by zero-valent iron, Ground Water 32 (1994) 958-967.

[2] L.J. Matheson, P.G. Tratnydk, Reductive dehalogenation of chlorinated methanes by iron metal, Environ. Sci. Technol. 28 (1994) 2045-2053.

[3] W.S. Orth, R.W. Gillham, Dechlorination of trichloroethene in aqueous solution using $\mathrm{Fe}^{0}$, Environ. Sci. Technol. 30 (1996) 66-71.

[4] A. Agrawal, P.G. Tratnyek, Reduction of nitro aromatic compounds by zero-valent iron metal, Environ. Sci. Technol. 30 (1996) 153160.

[5] G.D. Sayles, G. You, M. Wang, M.J. Kupferle, DDT, DDD, and DDE dechlorination by zero-valent iron, Environ. Sci. Technol. 31 (1997) 3448-3454.

[6] O. Schlicker, M. Ebert, M. Fruth, M. Weidner, W. Wüst, A. Dahmke, Degradation of TCE with iron: the role of competing chromate and nitrate reduction, Ground Water 38 (2000) 403-409.

[7] K.J. Cantrell, D.I. Kaplan, T.W. Wietsma, Zero-valent iron for the in situ remediation of selected metals in groundwater, J. Hazard. Mater. 42 (1995) 201-212.
[8] A.R. Pratt, D.W. Blowes, C.J. Ptacek, Products of chromate reduction on proposed subsurface remediation material, Environ. Sci. Technol. 31 (1997) 2492-2498.

[9] S.M. Ponder, J.G. Darab, T.E. Malloiuk, Remediation of $\mathrm{Cr}(\mathrm{VI})$ and $\mathrm{Pb}$ (II) aqueous solutions using supported, nanoscale zero-valent iron, Environ. Sci. Technol. 34 (2000) 2564-2569.

[10] M.J. Alowitz, M.M. Scherer, Kinetic of nitrate, nitrite and $\mathrm{Cr}(\mathrm{VI})$ reduction by iron metal, Environ. Sci. Technol. 36 (2002) 299-306.

[11] S. Bang, G.P. Korfiatis, X. Meng, Removal of arsenic from water by zero-valent iron, J. Hazard. Mater. 121 (2005) 61-67.

[12] D.P. Siantar, C.G. Scheier, C.S. Chou, Treatment of 1,2-dibromo-3chloropropane and nitrate-contaminated water with zero-valent iron or hydrogen/palladium catalysts, Water Res. 30 (1996) 2315-2322.

[13] I.F. Cheng, R. Muftikian, Q. Fernando, N. Korte, Reduction of nitrate to ammonia by zero-valent iron, Chemosphere 35 (1997) 2689-2695.

[14] C.P. Huang, H.W. Wang, P.C. Chiu, Nitrate reduction by metallic iron, Water Res. 32 (1998) 2257-2264.

[15] L.L. Zawaideh, T.C. Zhang, The effects of $\mathrm{pH}$ and addition of an organic buffer (HEPE) on nitrate transformation in $\mathrm{Fe}^{0}$-water system, Water Sci. Technol. 38 (1998) 107-115.

[16] J. Kielemoes, P.D. Boever, W. Verstraete, Influence of denitrification on the corrosion of iron and stainless steel powder, Environ. Sci. Technol. 34 (2000) 663-671.

[17] Y.H. Huang, T.C. Zhang, Kinetics of nitrate reduction by iron at near neutral pH, J. Environ. Eng. 128 (2002) 604-611.

[18] P. Westerhoff, Reduction of nitrate, bromate, and chlorate by zero valent iron $\left(\mathrm{Fe}^{0}\right)$, J. Environ. Eng. 129 (2003) 10-16.

[19] P. Westerhoff, J. James, Nitrate removal in zero-valent iron packed columns, Water Res. 37 (2003) 1818-1830.

[20] S. Choe, H.M. Liljestrand, J. Khim, Nitrate reduction by zero-valent iron under different pH regimes, Appl. Geochem. 19 (2004) 335342.

[21] Y.H. Huang, T.C. Zhang, Effects of low $\mathrm{pH}$ on nitrate reduction by iron powder, Water Res. 38 (2004) 2631-2642.

[22] C. Su, R.W. Puls, Nitrate reduction by zerovalent iron; effects of formate, oxalate, citrate, chloride, sulfate, borate, and phosphate, Environ. Sci. Technol. 38 (2004) 2715-2720.

[23] L.J. Puckett, Identifying the major sources of nutrient water pollution, Environ. Sci. Technol. 29 (1995) 408A-414A.

[24] World Health Organization, Health Hazards from Nitrates in Drinking Water, WHO Regional Office for Europe, Copenhagen, 1985.

[25] K. Ritter, M.S. Odziemkowski, R.W. Gillham, An in situ study of the role of surface films on granular iron in the permeable iron wall technology, J. Contam. Hydrol. 55 (2002) 87-111.

[26] C.B. Wang, W.X. Zhang, Synthesizing nanoscale iron particles for rapid and complete dechlorination of TCE and PCBs, Environ. Sci. Technol. 31 (1997) 2154-2156.

[27] W.X. Zhang, C.B. Wang, H.L. Lien, Treatment of chlorinated organic contaminants with nanoscale bimetallic particles, Catal. Today 40 (1998) 387-395.

[28] H.L. Lien, W.X. Zhang, Transformation of chlorinated methanes by nanoscale iron particles, J. Environ. Eng. 125 (1999) 1042-1047.

[29] H.L. Lien, W.X. Zhang, Nanoscale iron particles for complete reduction of chlorinated ethenes, Colloids Surf. A: Physicochem. Eng. Aspects 191 (2001) 97-105.

[30] Y. Xu, W.X. Zhang, Subcolloidal Fe/Ag particles for reductive dehalogenation of chlorinated benzenes, Ind. Eng. Chem. Res. 39 (2000) 2238-2244.

[31] D.W. Elliott, W.X. Zhang, Filed assessment of nanoscale bimetallic particles for groundwater treatment, Environ. Sci. Technol. 35 (2001) 4922-4926.

[32] B. Schrick, J.L. Blough, A.D. Jones, T.E. Mallouk, Hydrodechlorination of trichloroethylene to hydrocarbons using bimetallic nickel-iron nanoparticles, Chem. Mater. 14 (2002) 5140-5147.

[33] S. Choe, Y.Y. Chang, K.Y. Hwang, J. Khim, Kinetic of reductive denitrification by nanoscale zero-valent iron, Chemosphere 41 (2000) 1307-1311 
[34] P.M.L. Bonin, W. Jedral, M.S. Odziemkowski, R.W. Gillham, Electrochemical and raman spectroscopic studies of the influence of chlorinated solvents on the corrosion behaviour of iron in borate buffer and in simulated groundwater, Corros. Sci. 42 (2000) 19211939.

[35] D.F. Boltz, M.J. Taras, In Colorimetric Determination of Nonmetals, Wiley, New York, 1978, p. 210.

[36] C.J. Lin, S.L. Lo, Y.H. Liou, Dechlorination of trichloroethylene in aqueous solution by noble metal-modified iron, J. Hazard. Mater. 116 (2004) 219-228.

[37] Y. Liu, F. Yang, P.L. Yue, G. Chen, Catalytic dechlorination of chlorophenols in water by palladium/iron, Water Res. 35 (2001) 1887-1890.

[38] M.M. Scherer, J.C. Westall, M. Ziomek-Moroz, P.G. Tratnyek, Kinetics of carbon tetrachloride reduction at an oxide-free iron electrode, Environ. Sci. Technol. 31 (1997) 2385-2391.

[39] C. Su, R.W. Puls, Kinetics of trichloroethene reduction by zerovalent iron and tin: pretreatment effect, apparent activation energy, and intermediate products, Environ. Sci. Technol. 33 (1999) 163 168.

[40] M. Spiro, Chemical kinetics, in: R.G. Compton (Ed.), Reactions the Liquid-Solid Interface, vol. 28, Elsevier, Amsterdam, 1989, pp 69-166.

[41] I.F. Cheng, Q. Fernando, N. Korte, Electrochemical dechlorination of 4-chlorophenol to phenol, Environ. Sci. Technol. 31 (1997) 1074-1078.

[42] G.C.C. Young, H.L. Lee, Chemical reduction of nitrate by nanosized iron: kinetics and pathway, Water Res. 39 (2005) 884-894.

[43] J. Warna, I. Turunen, T. Salmi, T. Maunula, Kinetic of nitrate reduction in monolith reactor, Chem. Eng. Sci. 49 (1994) 5763-5773.

[44] U. Prusse, K.D. Vorlop, Supported bimetallic palladium catalysts for water-phase nitrate reduction, J. Mol. Catal. A: Chem. 173 (2001) 313-328.

[45] S. Horold, K.D. Vorlop, T. Tacke, M. Sell, Development of catalysts for a selective nitrate and nitrite removal from drinking water, Catal. Today 17 (1993) 21-30. 